\title{
MENINGKATKAN MINAT BACA SISWA MELALUI GERAKAN MAJALAH DINDING KELAS
}

\author{
WIDAYAT UMAR \\ SMP Negeri 2 Yogyakarta \\ e-mail: w.umar12yk@gmail.com
}

\begin{abstract}
ABSTRAK
Best practice ini bertujuan untuk: (1) mengetahui pelaksanaan peningkatan minat baca siswa melalui gerakan majalah dinding (mading) kelas di SMP Negeri 2 Yogyakarta; (2) mengetahui dampak positif dari kegiatan gerakan mading kelas terhadap peningkatan minat baca siswa di SMP Negeri 2 Yogyakarta. Best practice ini merupakan pengalaman penulis dalam upaya meningkatkan minat baca siswa melalui gerakan mading kelas. Data diperoleh dengan pengamatan dan pengisian angket. Data dianalisis secara deskreptif komparatif dari hasil pengamatan dan pengisian angket selama tiga kali. Hasil best practice menunjukkan bahwa gerakan mading kelas dengan tahapan: menentukan tema mading, membagi tema mading, membuat mading, memajang mading, mengunjungi, melihat dan membaca mading, serta lomba mading yang dilaksanakan dengan sistem berkala telah dapat meningkatkan minat baca siswa. Hasil analisis data dari angket yang telah diisi siswa menunjukkan bahwa dilihat dari tiga aspek yaitu aspek pemusatan perhatian, motivasi membaca, dan usaha membaca, melalui 3 kali pembuatan mading kelas, menunjukkan adanya peningkatan minat baca. Pada pelaksanaan gerakan mading kelas pertama, hasil penilaian minat baca siswa cukup baik, pada pelaksanaan kedua hasilnya baik, dan pelaksanaan ketiga hasilnya amat baik. Dengan demikian program ini akan terus dilanjutkan dengan harapan minat baca para siswa terus dapat ditingkatkan.
\end{abstract}

Kata kunci: minat baca, gerakan, majalah dinding

\section{PENDAHULUAN}

Undang-undang Pendidikan Nasional Nomor 20 Tahun 2003 menyatakan bahwa pendidikan nasional bertujuan untuk berkembangnya potensi peserta didik agar menjadi manusia yang beriman dan bertakwa kepada Tuhan Yang Maha Esa, berakhlak mulia, sehat, berilmu, cakap, kreatif, mandiri, dan menjadi warga negara yang demokratis serta bertanggung jawab. Menurut Kasiyun (2015), penguasaan ilmu pengetahuan dan teknologi akan dapat diraih apabila memiliki minat baca yang tinggi. Mufidah,dkk (2019) juga menyatakan bahwa manfaat dari membaca adalah membuat daya piker seseorang meningkat, sehingga dapat memahami segala sesuatu dengan mudah. Dengan besarnya manfaat membaca bagi siswa seharusnya dalam diri siswa memiliki minat baca yang tinggi.

Upaya untuk meningkatkan minat baca siswa di SMP Negeri 2 Yogyakarta sudah dilakukan. Diantaranya adalah dengan penambahan buku bacaan di perpustakaan, penjadwalan secara klasikal jam kunjung perpustakaan saat guru melaksanakan KBM, kegiatan literasi berupa 15 menit membaca buku sebelum KBM, dan sebagainya. Namun semua usaha tersebut belum membuahkan hasil yang signifikan. Hal ini nampak dalam keseharian masih banyak siswa yang tidak memanfaatkan waktu luang untuk membaca, bahkan ketika para guru mendapat tugas dinas yang terpaksa meninggalkan kelas, para siswapun lebih banyak ngobrol untuk menghabiskan waktu setelah tugas selesai dikerjakan. Upaya lain yang dilakukan sekolah untuk menumbuhkan minat baca adalah dengan mengadakan lomba minat baca berupa meringkas dan menceritakan kembali buku yang sudah dibaca. Kegiatan inipun hanya berdampak sesaat terhadap minat baca siswa. Pada saat akan menghadapi lomba para siswa nampak meningkat minat bacanya, namun setelah kegiatan lomba selesai, situasi kembali semula dimana budaya baca siswa tidak nampak lagi.

. Usaha untuk meningkatkan minat baca perlu terus dilakukan. Hasil penelitian yang dilakukan oleh Ati dan Widiyarto (2020) menunjukkan bahwa kegiatan literasi bahasa dapat 
meningkatkan minat baca siswa SMP. Hasil penelitian lain yang dilakukan oleh Rofi'udin dan Hermintoyo (2017) menunjukkan bahwa layanan pojok baca dapat meningkatkan minat baca siswa SMP. Temuan lain adalah hasil penelitian Pratiwi dan Sudibyo (2018) menunjukkan bahwa pembelajaran dengan media komik dapat meningkatkan minat baca siswa SMP. Dari beberapa pengalaman peneltian tersebut perlu dilakukan alternatif lain untuk meningkatkan minat baca siswa dengan melaksanakan best practice berupa gerakan mading kelas secara berkala dan berkelanjutan. Kegiatan best practice ini untuk menjawab permasalahan sebagai berikut: (1) bagaimanakah pelaksanaan peningkatan minat baca siswa melalui gerakan mading kelas di SMP Negeri 2 Yogyakarta?, dan (2) apakah gerakan mading kelas memiliki dampak positif pada minat baca siswa di SMP Negeri 2 Yogyakarta?

Membaca adalah suatu proses yang dilakukan serta dipergunakan oleh pembaca untuk memperoleh pesan, yang hendak disampaikan oleh penulis melalui media kata-kata/bahasa tulis (Tarigan, 2008:7). Adapun Rahim (2008:28) mengemukakan bahwa minat baca ialah keinginan yang kuat disertai usaha-usaha seseorang untuk membaca. Seseorang yang mempunyai minat membaca yang kuat akan diwujudkannya dalam kesediaannya untuk mendapat bahan bacaan dan kemudian membacanya atas kesadaran sendiri atau dorongan dari luar. Sedangkan Wahadaniah (1997:16) menyatakan bahwa minat baca adalah suatu perhatian yang kuat dan mendalam disertai dengan perasaan senang terhadap kegiatan membaca sehingga dapat mengarahkan seseorang untuk membaca dengan kemauannya sendiri atau dorongan dari luar.

Dari pendapat di atas dapat disimpulkan bahwa minat baca terkandung unsur perhatian, keinginan, usaha untuk membaca. Minat baca adalah suatu kecenderungan kepemilikan keinginan atau ketertarikan yang kuat dan disertai usaha-usaha yang terus menerus pada diri seseorang terhadap kegiatan membaca yang dilakukan secara terus menerus tanpa paksaan, atas keinginannya sendiri atau dorongan dari luar sehingga seseorang tersebut mengerti atau memahami yang dibacanya.

Mading merupakan satu jenis media komunikasi massa tulis yang paling sederhana. Disebut majalah dinding karena prinsip majalah terasa dominan di dalamnya, sementara itu penyajiannya biasanya dipampang pada dinding atau yang sejenisnya (Nursisto, 1999:1)

Menurut Supriyanto (dalam Saliwangi, 1992:2) mading sangat mungkin diselenggarakan karena merupakan salah satu bentuk majalah sekolah yang sederhana dengan biaya yang murah sehingga lebih mungkin dilaksanakan di mana saja. Kehadirannya di sekolah bukan saja disikapi sebagai pelengkap fasilitas semata, tetapi juga telah menjadi kebutuhan dalam merekayasa siswa, baik yang berkaitan dengan program kurikulum kurikuler maupun kokurikuler (Widodo, 1992:1). Selain itu mading juga berperanan sebagai salah satu fasilitas kegiatan siswa secara fisikal dan faktual serta memiliki sejumlah fungsi, yaitu : (1) informatif, (2) komunikatif (3) rekreatif, (4) kreatif (Widodo, 1992:1)

Berdasarkan berbagai pendapat di atas dapat disimpulkan bahwa mading dapat menjadi sarana berlatih untuk membina kreativitas menulis dan modal penanaman gemar membaca para siswa. Oleh karena itu dengan adanya mading diharapkan para siswa memiliki minat untuk memanfaatkan berbagai bahan pustaka yang ada di perpustakaan sekolah sebagai bahan rujukan dalam membuat karya tulis dan sekaligus untuk memupuk kegemaran dan kebiasaan membaca.

Gerakan mading kelas adalah kegiatan bersama-sama dalam satu sekolah membuat mading yang dilakukan oleh kelompok siswa di setiap kelas secara berkelanjutan. Adapun tujuan dari gerakan mading kelas adalah sebagai berikut: (1) Menciptakan budaya membaca dan menulis di kalangan para siswa; (2) Meningkatkan minat baca para siswa; (3) Menciptakan program sekolah yang melibatkan banyak siswa; dan (4) Membangun team work yang kuat pada kelompok belajar siswa. 
Penelitian ini merupakan penelitian deskriptif yang memberikan gambaran tentang pendampingan dan pembimbingan siswa dengan metode yang diterapkan untuk mencapai hasil yang diinginkan. Sasaran dari penelitian ini adalah siswa SMP Negeri 2 Yogyakarta yang tergabung dalam kelompok mading kelas yang terdiri dari 21 kelas. Sarana pendukung kegiatan penelitian berupa papan mading kelas, buku-buku perpustakaan, dan sarana lain yang ada di lingkungan sekolah. Kegiatan penelitian berupa gerakan mading kelas untuk meningkatkan minat baca siswa. Gerakan mading kelas memberikan kesempatan siswa untuk membaca buku sesuai tema mading yang disusun. Dengan tema yang bervariasi mendorong minat siswa untuk membaca berbagai judul buku yang berdampak pada pengetahuan siswa semakin meningkat.

Untuk melaksanakan gerakan mading kelas yang dapat meningkatkan minat baca siswa dibutuhkan prosedur pelaksanaannya, yaitu langkah-langkah yang harus dilakukan. Langkah-langkah tersebut sebagai berikut: (1) Rapat koordinasi dengan wakil kepala sekolah, guru, dan staf tata usaha; (2) Pembentukan tim pembimbing mading; (3) Sosialisasi kepada orang tua, siswa dan masyarakat; (4) Membentuk satuan tugas mading kelas; dan (5) Melaksanakan gerakan mading kelas. Kegiatan gerakan mading kelas dilakukan secara berkala dan berkelanjutan sehari setelah pelaksanaan penilaian tengah semester.

Gerakan mading kelas dipilih sebagai strategi pemecahan masalah untuk dapat meningkatkan minat baca siswa dengan alasan sebagai berikut.

1. Gerakan mading kelas mendorong siswa di setiap kelas melakukan aktivitas menulis sesuai tema yang dipilih.

2. Untuk dapat menuangkan karya tulis di mading, siswa harus memiliki ide dan pengetahuan sesuai tema mading yang ditulis.

3. Untuk meningkatkan pengetahuan dan ide, para siswa harus membaca banyak literatur dari berbagai sumber salah satunya dengan membaca buku.

4. Gerakan mading kelas yang dilakukan secara berkala dan berkelanjutan memotivasi siswa melakukan aktivitas membaca buku secara berkelanjutan yang akhirnya terbentuklah budaya membaca di kalangan para siswa.

Gerakan mading kelas dipilih sebagai solusi yang dapat meningkatkan minat baca siswa di SMP Negeri 2 Yogyakarta dilakukan dengan strategi sebagai berikut.

1. Penentuan tema mading. Tema mading ditentukan oleh tim pembimbing. Waktu penentuan tema dilaksanakan secara berkala 2 bulan sebelum pembuatan mading kelas.

2. Pembagian tema mading. Tema mading dibagikan secara acak kepada setiap kelas.

3. Pembuatan mading. Siswa membuat mading setelah selesai megikuti kegiatan penilaian tengah semester.

4. Pemajangan mading. Setelah karya mading diselesaikan, seluruh mading dipajang secara terbuka di aula sekolah.

5. Kunjungan mading. Puncak dari kegiatan gerakan mading kelas adalah kunjungan majalah dinding. Hal ini dilakukan oleh para siswa, guru, orang tua, dan masyarakat.

6. Lomba mading. Kegiatan ini dilakukan pada saat pemajangan mading ketiga.

Adapun untuk mengetahui dampak dari gerakan mading kelas terhadap minat baca siswa, dikembangkan instrumen berupa angket dengan komponen meliputi (1) pemusatan perhatian (2) motivasi untuk membaca, dan (3) usaha untuk membaca. Adapun pengambilan data dilakukan setelah pelaksanaan pembuatan mading setiap semesternya kepada 2 orang siswa di setiap kelas secara acak dengan jumlah 42 siswa.

Sedangkan hasil isian angket disajikan seperti dalam Tabel 1 dan dianalisis secara deskriptif untuk menunjukkan rata-rata dan kategori minat baca.

Tabel 1. Penyajian Hasil Isian Angket Minat Baca Setiap Putaran

\begin{tabular}{llllll}
\hline No & Aspek Minat Baca & Terendah & $\begin{array}{c}\text { Nilai } \\
\text { Tertinggi }\end{array}$ & Rerata & Kategori \\
\hline
\end{tabular}

1. Pemusatan perhatian 
2. Motivasi membaca

3. Usaha membaca

\section{HASIL DAN PEMBAHASAN}

Hasil

Untuk mengetahui kondisi awal minat baca siswa, pada hari abu, 2 Agustus 2017 dilaksanakan pengisian angket minat baca siswa terhadap 2 siswa di setiap kelas. Hasil isian angket dianalisis dan hasilnya nampak bahwa minat baca siswa dari semua komponen minat baca yaitu pemusatan perhatian, motivasi membaca, dan usaha membaca menunjukkan dalam kategori kurang baik seperti yang tertera pada tabel 2.

Tabel 2. Hasil Awal Pengisian Angket Minat Baca Siswa

\begin{tabular}{clcccc}
\hline \multirow{2}{*}{ No } & Komponen Minat Baca & Terendah & $\begin{array}{c}\text { Nilai } \\
\text { Tertinggi }\end{array}$ & Rerata & Kategori \\
\hline 1. & Pemusatan perhatian & 10 & 21 & 15 & Kurang baik \\
2. & Motivasi membaca & 10 & 19 & 15 & Kurang baik \\
3. & Usaha membaca & 10 & 19 & 15 & Kurang baik \\
\hline
\end{tabular}

Dengan kondisi awal tersebut telah dilakukan upaya peningkatan minat baca melalui gerakan mading kelas secara berkala selama 3 kali dari semester 1 tahun pelajaran 2017/2018 sampai semester 1 tahun pelajaran 2018/2019 dengan strategi di setiap pelaksanaan sebagai berikut. Pertama, guru pendamping menentukan tema mading seperti masalah budaya, kesehatan, lingkungan, bahaya narkoba, kuliner, tehnologi, olah raga, dan sebagainya. Untuk putaran pertama tema mading ditentukan di awal bulan September 2017. Langkah kedua yaitu membagi tema mading secara acak ke setiap kelas. Setelah memperoleh tema mading, maka setiap siswa di kelas tersebut wajib membaca buku yang terkait dengan tema. Setelah para siswa membaca buku, mereka didorong untuk membuat ide atau gagasan yang dituangkan dalam karya yang nantinya akan digunakan untuk membuat mading. Karya siswa bisa berupa artikel, opini, puisi, atau gambar. Kegiatan ini dilakukan di sekolah maupun di rumah kurang lebih tiga minggu menjelang pembuatan mading. Langkah ketiga adalah membuat mading. Untuk semester 1 tahun pelajaran 2017/2018 dilaksanakan pada hari Senin, 2 Oktober 2017 s.d Senin, 9 Oktober 2017. Pada rentang waktu tersebut para siswa melakukan proses diskusi menyortir karya siswa sesuai tema, melakukan tata letak, pewarnaan dan sebagainya yang aktivitasnya nampak seperti pada gambar 1 . Setelah proses penyiapan mading selesai maka pada hari Selasa, 10 Oktober 2017 seluruh siswa di setiap kelas menyusun mading kelas.
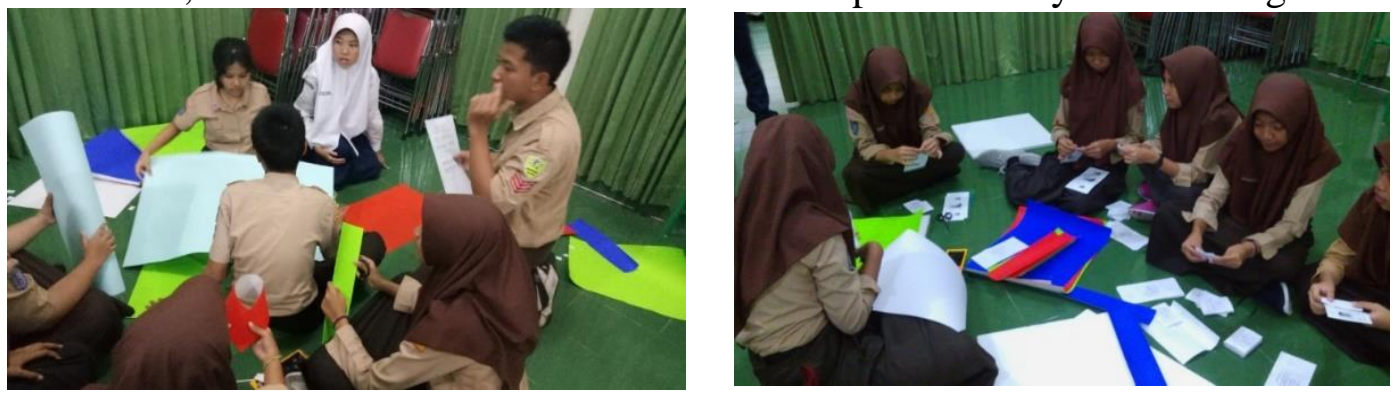

Gambar 1. Siswa antusias membuat mading dalam kelompok

Langkah keempat adalah memajang mading. Seperti pada semester 1 tahun pelajaran 2017/2018 dilaksanakan pada hari Rabu, 12 Oktober 2018 seperti nampak pada Gambar 2. Pemajangan mading ini dengan maksud agar siswa memiliki rasa bangga karena karya mereka dipajang ditempat terbuka dan dibaca oleh banyak orang. Tujuan lain adalah agar terjadi sikap saling mengapresiasi diantara para siswa atas karya-karya mereka.

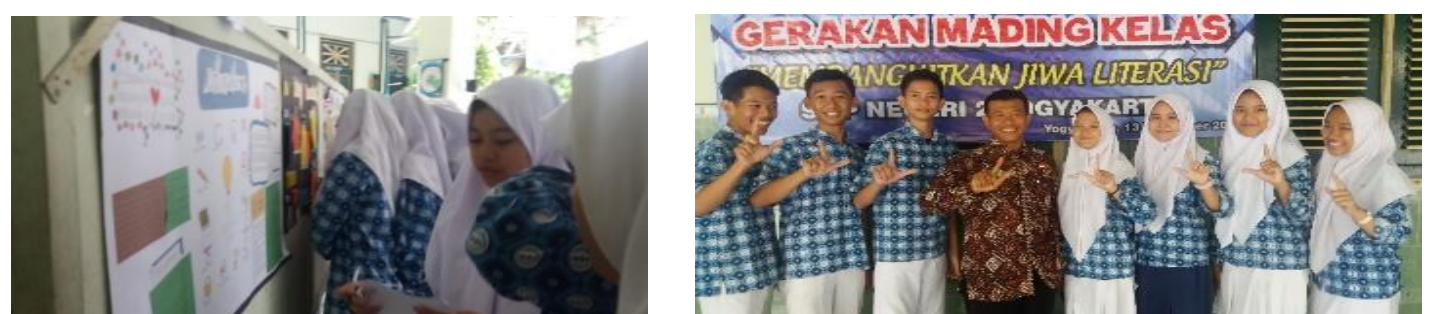




\section{Gambar 2 Para siswa memajang karya mading}

Langkah kelima berupa kegiatan mengunjungi mading, yaitu seluruh siswa dari berbagai kelas diberi tugas untuk mengunjung mading karya siswa kelas lain. Kegiatan ini memberi kesempatan siswa untuk membaca "belanja ilmu" karya siswa lain dengan tema yang berbeda. Hal ini berdampak pengetahuan dan wawasan siswa semakin bertambah. Hal ini nampak seperti pada gambar 3 .
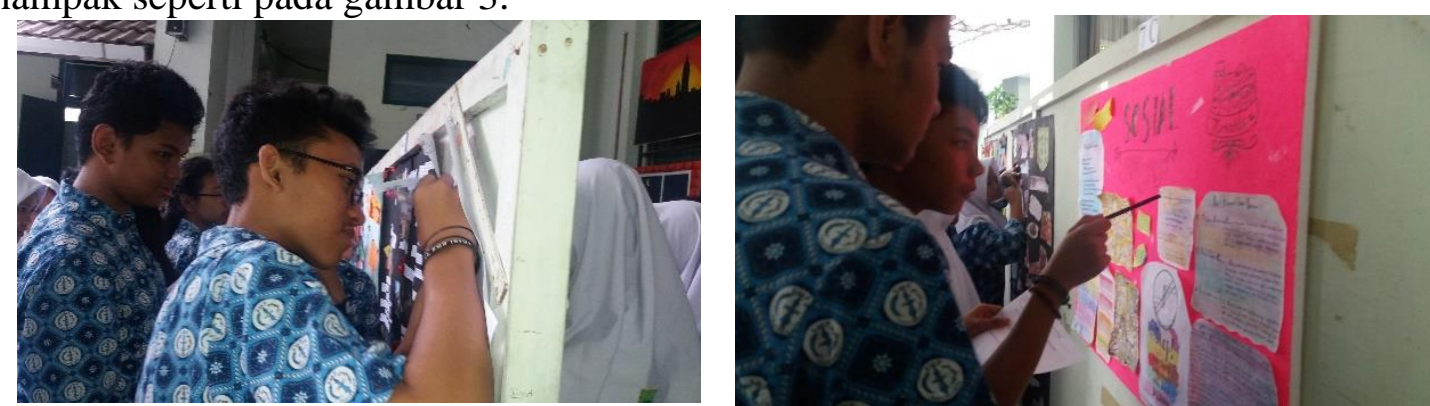

Gambar 3 Para siswa antusias melakukan "belanja ilmu"

Langkah keenam berupa kegiatan lomba mading. Kegiatan ini dilaksanakan pada saat pemajangan mading ketiga yaitu pada semester 1 tahun pelajaran 2018/2019. Hal ini dilakukan untuk memotivasi siswa agar lebih semangat dalam menyusun mading yang berdampak dalam peningkatan minat baca. Tim penilai yang terdiri dari para guru yang ditunjuk melakukan penilaian seluruh mading kelas yang dipajang dan hasilnya diberi penghargaan oleh kepala sekolah dan diumjumkan pada saat upacara bendera hari senin seperti pada Gambar 4.
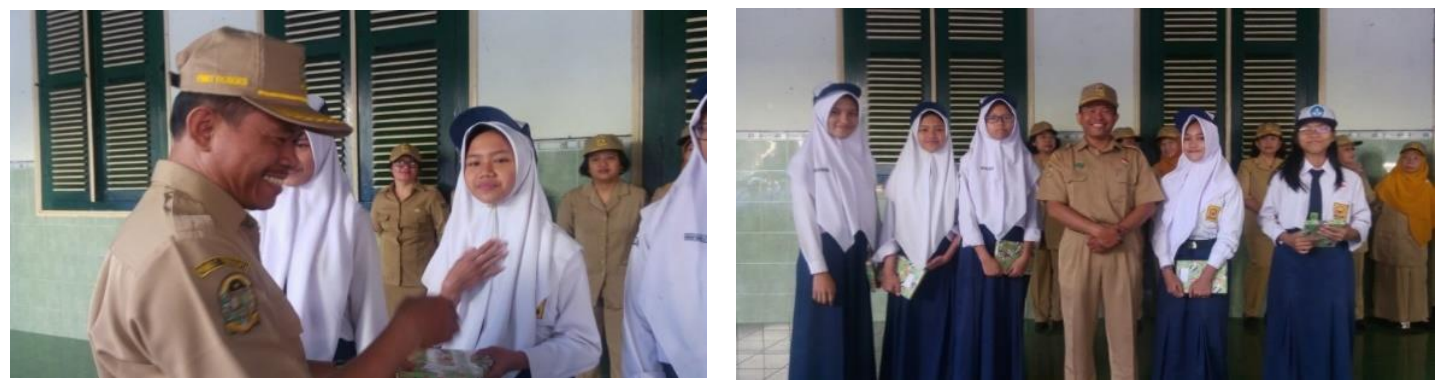

Gambar 4 Kepala sekolah memberikan penghargaan kepada para pemenang lomba mading kelas

Untuk mengetahui dampak dari kegiatan gerakan mading kelas terhadap peingkatan minat baca siswa, maka di akhir pembuatan mading kelas setiap semesternya dilakukan pengisian angket minat baca. Hasil analisis isian angket minat baca siswa setelah dilakukan gerakan mading kelas semester 1 tahun pelajaran 2017/2018 hasilnya tertera pada Tabel 3. Berdasarkan deskripsi data tersebut tampak bahwa minat baca pada komponen pemusatan perhatian memperoleh nilai rata-rata 21 , motivasi membaca memperoleh nilai rata-rata 20 , dan usaha membaca memperoleh nilai rata-rata 17. Ketiganya dalam kategori cukup baik. Hal ini sejalan dengan pengamatan penulis, selama proses pelaksanaan mading kelas, para siswa sudah mulai membaca buku walaupun belum intensif. Mereka membaca buku sekedar ingin mencari tema untuk membuat materi mading yang ditugaskan. 
Vol 1. No 3. Juli 2021 P-ISSN : 2774-8022, e-ISSN : 2774-5791

Tabel 3. Hasil Isian Angket Minat Baca Pertama

\begin{tabular}{llcccc}
\hline No & Komponen Minat Baca & Terendah & $\begin{array}{c}\text { Nilai } \\
\text { Tertinggi }\end{array}$ & $\begin{array}{c}\text { Kategori } \\
\text { minat }\end{array}$ \\
\hline 1. & Pemusatan perhatian & 12 & 28 & 21 & Cukup baik \\
2. & Motivasi membaca & 12 & 28 & 20 & Cukup baik \\
3. & Usaha membaca & 10 & 24 & 17 & Cukup baik \\
\hline
\end{tabular}

Hasil analisis isian angket minat baca siswa setelah dilakukan gerakan mading kelas pada semester 2 tahun pelajaran 2017/2018 hasilnya tertera pada Tabel 4 berikut.

Tabel 4. Hasil Isian Angket Minat Baca Kedua

\begin{tabular}{llcccc}
\hline No & Komponen Minat Baca & Terendah & $\begin{array}{c}\text { Nilai } \\
\text { Tertinggi }\end{array}$ & Rerata & $\begin{array}{c}\text { Kategori } \\
\text { minat }\end{array}$ \\
\hline 1. & Pemusatan perhatian & 23 & 31 & 25 & Baik \\
2. & Motivasi membaca & 23 & 29 & 26 & Baik \\
3. & Usaha membaca & 19 & 27 & 22 & Baik \\
\hline
\end{tabular}

Berdasarkan deskripsi data tersebut tampak bahwa minat baca pada komponen pemusatan perhatian memperoleh nilai rata-rata 25 , motivasi membaca memperoleh nilai ratarata 26, dan usaha membaca memperoleh nilai rata-rata 27 . Ketiganya dalam kategori baik. Hal ini sejalan dengan pengamatan penulis saat proses penyusunan mading kedua. Dengan adanya tantangan bahwa karya mereka akan dicatat oleh siswa lain maka mendorong mereka membuat karya yang terbaik, salah satu upayanya adalah dengan membaca buku sebanyakbanyaknya agar mendapatkan ide yang lebih menarik dan dituangkan dalam karya mading. Hasil analisis isian angket minat baca siswa setelah dilakukan gerakan mading kelas ketiga yaitu pada semester 1 tahun pelajaran 2018/2019 hasilnya tertera pada Tabel 5 berikut.

Tabel 5. Hasil Isian Angket Minat Baca Ketiga

\begin{tabular}{llcccc}
\hline No & Komponen Minat Baca & \multicolumn{3}{c}{ Nilai } & $\begin{array}{c}\text { Kategori } \\
\text { minat }\end{array}$ \\
\hline 1. & Pemusatan perhatian & 23 & 34 & 29 & Sangat baik \\
2. & Motivasi membaca & 24 & 34 & 30 & Sangat baik \\
3. & Usaha membaca & 21 & 28 & 25 & Sangat baik \\
\hline
\end{tabular}

Berdasarkan deskripsi data tersebut tampak bahwa minat baca pada komponen pemusatan perhatian memperoleh nilai rata-rata 29 , motivasi membaca memperoleh nilai ratarata 30, dan usaha membaca memperoleh nilai rata-rata 25 . Ketiganya dalam kategori sangat baik. Hal ini sejalan dengan hasil pengamatan penulis pada saat proses pelaksanaan mading kelas ketiga. Dengan adanya pemberitahuan dari kepala sekolah bahwa karya mereka akan dilombakan dan akan diberi hadiah bagi yang karyanya terbaik, mendorong mereka lebih meningkatkan diri dalam banyak membaca buku sehingga memunculkan ide untuk membuat karya mading yang kreatif dan inovatif.

\section{Pembahasan}

Kegiatan best practice ini dilakukan untuk meningkatkan minat baca siswa melalui kegiatan gerakan mading kelas. Dengan kata lain gerakan mading kelas sebagai stimulus para siswa agar memiliki kesadaran membaca dari diri sendiri dan bukan karena paksaan. Hal ini sesuai yang dinyatakan Kasiyun (2015) bahwa upaya meningkatkankan minat baca siswa dengan memaksa membaca buku sebanyak-banyaknya tidaklah efektif. Pengungkapan kondisi awal tentang minat baca siswa berdasarkan komponen pemusatan perhatian, komponen motivasi membaca, dan komponen usaha membaca untuk memperoleh gambaran konkrit 
tentang perilaku siswa terkait minat baca yang selanjutnya diberikan tindakan berupa kegiatan gerakan mading kelas.

Hasil pengamatan awal diperoleh data bahwa minat baca siswa dilihat dari komponen pemusatan perhatian, komponen motivasi membaca, dan komponen usaha membaca dalam kategori kurang baik. Setelah dilaksanakan kegiatan gerakan mading kelas yang dilakukan secara berkala dari pembuatan mading pertama sampai pembuatan mading ketiga diperoleh data bahwa adanya peningkatan minat baca siswa. Hal ini ditunjukkan dengan hasil penilaian minat baca pertama sampai ketiga mengalami peningkatan berdasarkan perolehan skor masing-masing indikator minat baca.

Pada komponen pemusatan perhatian secara berturut-turut dari penilaian pertama, kedua, dan ketiga rata-rata skor mengalami peningkatan. yaitu 21, 25, dan 29 dengan kategori meningkat dari cukup baik, baik, dan sangat baik. Demikian juga pada komponen motivasi belajar, secara berturut-turut dari penilaian pertama, kedua, dan putaran ketiga rata-rata skor mengalami peningkatan yaitu 20,26, dan 30 dengan kategori meningkat dari cukup baik, baik, dan sangat baik. Sedangkan pada komponen usaha belajarpun juga megalami peningkatan rata-rata skor yaitu 17, 22, dan 25 dengan kategori meningkat dari cukup baik, baik, dan sangat baik. Hal ini mengindikasikan bahwa pelaksanaan gerakan mading kelas dapat meningkatkan minat baca siswa.

Gerakan mading kelas yang dilaksanakan secara berkala dan berkelanjutan serta melibatkan semua unsur sekolah yaitu siswa, guru, karyawan, orang tua, dan masyarakat terbukti dapat menjadi solusi atas masalah rendahnya minat baca siswa yang selama ini terjadi di SMP Negeri 2 Yogyakarta. Siswa sebagai subyek atau pelaku utama nampak semakin antusias dalam mengikuti gerakan mading kelas dari setiap semester. Keinginan siswa ingin menampilkan mading yang terbaik mendorong mereka untuk suka membaca buku lebih banyak dan rotin agar memiliki pengetahuan yang luas untuk dituangkan dalam mading kelas sesuai tema yang menjadi tugasnya. Keberadaan guru, karyawan, orangtua, dan masyarakat sangat memberikan motivasi yang besar kepada siswa untuk melakukan hasil karya yang terbaik. Arahan dan bimbingan guru menjadi jalan penerang bagi siswa untuk membuat karya yang lebih inovatif dan kreatif. Dukungan karyawan dalam hal penyiapan bahan dan sarana mading sangat membantu dan memperlancar tugas-tugas mereka. Apresiasi dan dukungan dari orang tua dan masyarakat berupa sumbangan buku dan kunjungan terhadap hasil karya mading yang dipajang/dipamerkan menambah siswa lebih bangga, percaya diri dan merasa dihargai.

Pada pelaksanaan gerakan mading kelas pertama telah berdampak peningkatan minat baca dari kondisi awal yang sebelumnya pada komponen pemusatan perhatian, motivasi membaca, dan usaha membaca dengan rata-rata semuanya 15 berkategori kurang baik meningkat pada komponen pemusatan perhatian, motivasi membaca, dan usaha membaca berturut-turut nilai rata-rata 21, 20, 17 dengan kategori semuanya cukup baik. Peningkatan belum signifikan, hal ini disebabkan para siswa dalam membaca buku masih sebatas memenuhi tugas agar bisa membuat mading. Belum nampak keinginan untuk menampilkan karya yang terbaik, sehingga buku yang dibaca sangat terbatas, dan mading yang dihasilkan masih terkesan asal jadi. Selain itu keberadaan satgas mading kelas nampaknya belum memberikan dampak yang signifikan terhadap antusias siswa untuk membuat mading kelas. Kondisi ini disebabkan juga oleh waktu yang disediaakan sangat terbatas yaitu hanya sekitar 2 minggu untuk persiapan.

Pengalaman pemajangan mading pada pelaksanaan pertama dan dikunjungi, dilihat, dan dibaca oleh semua siswa dan guru menyebabkan para siswa yang karyanya kurang menarik merasa malu dan terdorong untuk membuat mading lebih baik pada pelaksanaan berikutnya, dan yang sudah baik ingin lebih meningkatkan lagi. Pihak sekolahpun memberi waktu persiapan lebih lama yaitu sekitar satu bulan berupa pembagian tema. Dengan demikian para siswa lebih awal melakukan persiapan dengan melakukan aktivitas mencari buku dan membaca buku. Selain itu keberadaan guru pendamping ternyata berdampak positif 
terhadap motivasi siswa dalam membuat mading, mereka lebih antusias, lebih mau bekerja sama, berani menyampaikan usulan, dan lebih sering membaca buku agar lengkap mendapatkan informasi. Keadaan ini ternyata berdampak pada peningkatan minat baca siswa yaitu berturut-turut pada komponen pemusatan perhatian, motivasi membaca, dan usaha membaca dengan rata-rata 25,26 , dan 22 semua berkategori baik.

Peningkatan minat baca siswa setelah pelaksanaan gerakan mading kelas kedua mendorong semua pihak untuk terus berkoordinasi untuk melakukan perbaikan agar minat baca siswa terus dapat ditingkatkan. Maka pada pelaksanaan gerakan mading kelas pada putaran ketiga motivasi siswa terus didorong untuk dapat menciptakan karya mading kelas yang lebih berbobot, lebih inovatif, dan keratif. Salah satu dorongan yang diberikan adalah bahwa mulai putaran ketiga hasil karya mading kelas terbaik akan diberi apresiasi kejuaraan. Hal ini berdampak semakin antusiasnya siswa melakukan kegiatan membaca buku untuk mendapatkan ide terbaik agar mampu membuat mading yang berkualitas. Keadaan ini ternyata berdampak pada peningkatan minat baca siswa yaitu berturut-turut pada aspek pemusatan perhatian, motivasi membaca, dan usaha membaca dengan rata-rata 29, 30, dan 25 semua berkategori sangat baik.

Gerakan mading kelas ini dilaksanakan sebagai upaya untuk meningkatkan minat baca siswa. Zubaidah dan Saptono ( 2004) menyatakan mading kelas yang dikelola dengan baik dapat meningkatkan minat baca siswa. Adiyanto (2016) dalam penelitiannya meyatakan adanya mading kelas dapat merubah kebiasaan siswa dari pasif membaca menjadim aktif membaca.

Berdasarkan uraian di atas diperoleh gambaran bahwa gerakan mading kelas telah berdampak pada meningkatnya minat baca siswa di SMP Negeri 2 Yogyakarta. Hal ini nampak pada ringkasan hasil penilaian minat baca siswa seperti tertera pada Tabel 6 berikut ini.

Tabel 6. Rangkuman Hasil Penilaian Minat Baca Siswa

\begin{tabular}{clcccccc}
\hline \multirow{2}{*}{ No } & $\begin{array}{c}\text { Aspek Minat } \\
\text { Baca }\end{array}$ & \multicolumn{2}{c}{ Penilaian ke-1 } & \multicolumn{2}{c}{ Penilaian ke-2 } & \multicolumn{2}{c}{ Penilaian ke-3 } \\
& Rerata & Kategori & Rerata & Kategori & Rerata & Kategori \\
\hline 1. & $\begin{array}{l}\text { Pemusatan } \\
\text { perhatian }\end{array}$ & 20 & $\begin{array}{c}\text { cukup } \\
\text { baik }\end{array}$ & 25 & baik & 29 & sangat baik \\
2. & $\begin{array}{l}\text { Motivasi } \\
\text { membaca }\end{array}$ & 21 & $\begin{array}{c}\text { cukup } \\
\text { baik }\end{array}$ & 26 & baik & 30 & sangat baik \\
3. & $\begin{array}{l}\text { Usaha } \\
\text { membaca }\end{array}$ & 17 & $\begin{array}{c}\text { cukup } \\
\text { baik }\end{array}$ & 22 & baik & 25 & sangat baik \\
\hline
\end{tabular}

Dampak lain dari kegiatan gerakan mading kelas adalah terwujudnya budaya baca pada diri siswa. Nampak setiap hari para siswa telah memanfaatkan waktu luang untuk membaca buku, diantaranya waktu luang sebelum kegiatan belajar mengajar dimulai, maupun waktu luang lainnya. Mereka melakukan kegiatan membaca tidak hanya diperpustakaan namun juga di telasar-telasar kelas dan di pojok baca yang telah disediakan sekolah seperti nampak pada Gambar 5. 


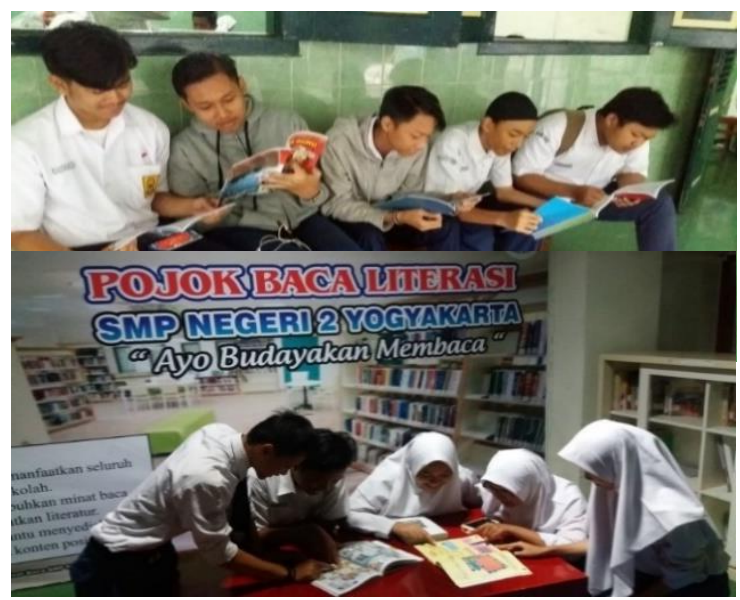

Gambar 5. Siswa mengisi waktu luang dengan kegiatan membaca

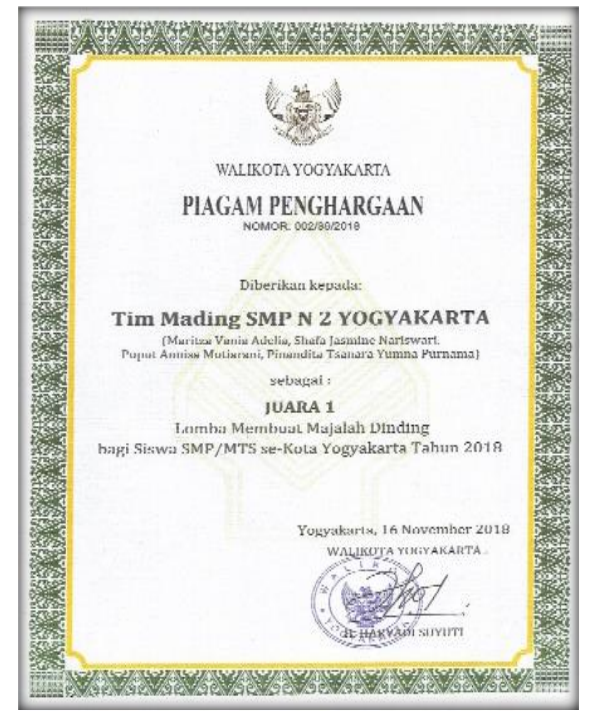

\section{Gambar 6. Piagam kejuaraan lomba mading (juara 1)}

Dampak berikutnya dari kegiatan pembuatan mading kelas yaitu para siswa memperoleh prestasi tinggi berupa keberhasilan dalam mengikuti lomba mading yang diselenggarakan oleh Dinas Perpustakaan dan Kearsipan Kota Yogyakarta pada bulan Oktober 2018 dengan meraih piagam penghargaan juara 1 seperti nampak pada Gambar 6.

\section{KESIMPULAN}

Berdasarkan hasil penelitian dan pembahasan dapat disimpulkan bahwa gerakan mading kelas dapat meningkatkan minat baca siswa. Hal ini ditunjukkan dengan adanya peningkatan skor dari penilaian pertama sampai penilaian ketiga berturut-turut 20, 25, dan 29 dengan kategori beturut-turut cukup baik, baik dan sangat baik pada aspek pemusatan perhatian. Untuk aspek motivasi membaca berturut-turut 21, 26, dan 30 dengan kategori cukup baik, baik, dan sangat baik. Peningkatan juga terjadi pada aspek usaha membaca yaitu berturut-turut 17, 22, dan 25 dengan kategori cukup baik, baik, dan sangat baik. Temuan lain dari pelaksanaan gerakan mading kelas yaitu: (1) tumbuhnya budaya membaca pada diri siswa dengan memanfaatkan waktu luang, dan (2) tumbuhnya budaya kompetesi positif untuk mencapai prestasi. Oleh sebab itu, gerakan mading kelas dapat dijadikan sebagai salah satu media pembelajaran yang memberikan kesempatan para siswa untuk bekerja kolaboratif, berfikir kritis, kreatif, dan komunikatif. 
DAFTAR PUSTAKA

Adiyanto. (2016). Program Literasi Sekolah Pemanfaatan Mading yang Terintegrasi Materi Pelajaran dalam Meningkatkan Minat Baca Siswa Kelas IV di SDN Guntur Kota Cirebon. Skripsi. Institut Agama Islam Bunga Bangsa Cirebon. Cirebon.

Ati, A.P. \& Widiyarto, S.(2020). Peran Literasi Bahasa dalam Meningkatkan Minat Baca dan Menulis pada Siswa SMP Kota Bekasi. Basastra. 9 (1), 105-113, from https://jurnal.unimed.ac.id/2012/index.php/basastra/article/view/17778

Kasiyun, S. (2015). Upaya Meningkatkan Minta Baca sebagai Sarana untuk Mencerdaskan Bangsa. Jurnal Rena Indonesia. 1 (1).79-95, from https://journal.unesa.ac.id/index.php/jpi/article/viewFile/140/61

Mufidah, D., Oktarina, E.S., Mawarni, K.P., \& Fadhila, S. (2019, 1 (2)). Pemetaan Kemampuan Membaca Pemahaman melalui Teks Eksplanasi. Proceeding Seminar Nasional. Bahasa dan Sastra Indonesia.Perkembangan Bahasa dan Sastra Masa Kini. Universitas Pamulang. Retrieved from http://www.openjournal.unpam.ac.id/index.php/Proceedings/article/view/4105

Nursisto. 1999. Membina Majalah Dinding.Yogyakarta : Adicita Karya Nusa.

Pratiwi, D.K.P. \& Sudibyo, E. (2018). Keefektifan Penggunaan Media Pembelajaran Komik Pada Materi Gerak Untuk Meningkatkan Minat Baca Siswa SMP Kelas VIII. Pensa E-Jurnal: Pendidikan Sains. 6 (2), 290-295, from https://ejournal.unesa.ac.id/index.php/pensa/article/view/24263

Rahim, F. 2008. Pengajaran Membaca di Sekolah Dasar. Jakarta : Bumi Aksara.

Rofi'udin, M.A. \& Hermintoyo. (2017). Pengaruh Pojok Baca Terhadap Peningkatan Minat Baca Siswa di SMP Negeri 3 Pati. Jurnal Ilmu Perpustakaan. 6 (1), 281-290, from https://ejournal3.undip.ac.id/index.php/jip/article/view/23086

Saliwangi, Basenang.1992. Diktat Pembuatan Majalah Dinding Sebagai Upaya Peningkatan Minat Baca Siswa di Kecamatan Sumbermanjing Wetan Kabupaten Malang. Malang : LPM IKIP MALANG

Tarigan, Henry Guntur. 2008. Membaca sebagai Suatu Keterampilan Berbahasa. Angkasa: Bandung.

Wahadaniah, Herman. 1997. Perpustakaan Sekolah sebagai Sarana Pengembangan Minat dan Kegemaran Membaca. Dalam Departemen Pendidikan dan Kebudayaan. Laporan Lokakarya Pengembangan Minat dan Kegemaran Membaca (hlm. 15-22) Jakarta: Departemen Pendidikan dan Kebudayaan.

Widodo, HS. 1992. Majalah Dinding sebagai Pembinaan Kreativitas Siswa. Makalah disajikan dalam Diklat Pembuatan Majalah Dinsing bagi Para Guru di SD di Kecamatan Sumbefmanjing Wetan Kabupaten Malang. Malang : LPM IKIP MALANG

Zubaidah, E \& Saptono, B. (2004). Pengelolaan Majalah Dinding di Sekolah. Jurnal Ilmiah Guru: COPE (Caraka Olah Pikir Edukatif). 8 (1), 35-42, from https://journal.uny.ac.id/index.php/cope/article/view/5431/4726 